引用格式: 曹瑞芬, 张安录. 跨区域财政转移制度的耕地保护效应: 以新增建设用地使用费为例 [J]. 资源科学, 2019, 41(9): 1714- 1723. [Cao R F, Zhang A L. Effect of transregional fiscal payment system for cultivated land protection: Taking new construction land compensation fees as an example[J]. Resources Science, 2019, 41(9): 1714-1723.] DOI: 10.18402/resci.2019.09.12

\title{
跨区域财政转移制度的耕地保护效应 以新增建设用地使用费为例
}

\author{
曹瑞芬 ${ }^{1}$, 张安录 $^{2}$ \\ (1. 浙江工商大学土地资源管理系,杭州 310018; \\ 2. 华中农业大学土地管理学院, 武汉 430070)
}

\begin{abstract}
摘 要: 跨区域财政转移制度是解决耕地保护区域非均衡的重要工具,其通过管制弱化区域和管制强化区域 之间的横向财政转移,使得不同区域均能享受到国土空间优化带来的福利提升,有助于耕地保护的实施。本文初 步尝试将新增费缴纳、新增费分配过程有机结合,视为横向跨区域财政转移支付,即新增费由建设用地指标多的非 农发展区流向耕地保护任务重的农地保护区, 并考察这种以新增费为载体的跨区域财政转移制度的耕地保护作用 机理。在此基础上,本文采用中国 2005-2015 年间省级面板数据,通过建立动态面板计量模型和引入系统 GMM 估计方法进行实证检验。研究结果表明: 以新增费为载体的省际横向跨区域财政转移制度有助于调动地方政府保 护耕地的积极性, 达到耕地保护的目的, 但是其发挥的作用非常有限。进一步探讨新增费的两个主要组成部分 ——新增费缴纳和新增费分配的耕地保护效应大小可知, 相比于新增费分配, 新增费缴纳的耕地保护效果更好。 本文研究结果有助于完善以新增费为载体的省际横向跨区域财政转移支付制度, 促进耕地资源保护。
\end{abstract}

关键词: 耕地保护; 效应分析; 跨区域财政转移制度; 新增费; 系统广义矩(SYS-GMM) 方法

DOI :10.18402/resci.2019.09.12

\section{1 引言}

改革开放以来, 中国的经济发展水平突飞猛 进,GDP 总量自 2010 年起仅次于美国, 位列全球第 二。然而, 随着经济的迅速发展, 城市扩张速度加 快, 中国的耕地资源流失非常严重, 耕地面积由 1978 年的 14962.54 万 $\mathrm{hm}^{2}$ 减少到 2016 年的 13492.09 万 $\mathrm{hm}^{2[1]}$, 年均减少 38.70 万 $\mathrm{hm}^{2}$ 。众所周 知, 耕地资源具有强烈的外部性, 其除了具备基本 的生产功能外, 还能产生生态效益和社会效益 ${ }^{[2,3]}$, 耕地资源大量流失会导致粮食危机 ${ }^{[4-6]}$ 和生态危机 ${ }^{[7,8]}$ 等, 不利于社会稳定 ${ }^{[0]}$ 。

就地区差异来说, 由于外部性的存在, 农地的 经济利益较低, 因此, 相比于非农发展区, 农地保护
区的经济发展水平滞后。同时,地方政府的财政收 人与当地的经济发展水平密切相关 ${ }^{[10]}$, 分税制改革 后，地方政府的财政不仅取决于中央和地方的收人 分成,而且取决于本地经济发展的财政规模,通过 扩张 GDP 以增加财政收人 ${ }^{[1]}$ 。换言之, 建设用地指 标越多的地区, 经济发展水平越高, 财政收人能力 越强; 而耕地保护任务重的地区, 经济发展水平较 低,财政收人能力较弱。雍新琴等 ${ }^{[12]}$ 指出, 从区域的 角度来说, 实施耕地保护制度造成的利益损失, 在 中国表现为地方政府财政收人的减少。地方政府 是耕地保护的重要主体,陷人财政困境势必会削弱 其保护耕地的积极性, 影响耕地保护效果。因此, 实行跨区域财政转移支付制度迫在眉睫。

收稿日期: 2018-12-10 修订日期: 2019-06-25

基金项目: 国家自然科学基金项目 (71904173); 教育部人文社会科学研究青年基金项目 (17YJC790004); 浙江省社科规划课题 (18NDJC183YB)。

作者简介: 曹瑞芬,女,湖北钟祥人,博士,讲师,主要研究方向为土地资源经济。E-mail: cao.ruifen@163.com 
究,借此检验以新增费为载体的跨区域财政转移制

近年来,有关耕地保护跨区域补偿机制的研究 逐渐兴起, 但主要集中在补偿机制构建、补偿标准 测算和补偿区域划分上。余亮亮等 ${ }^{[13]}$ 通过实证检验 国土空间规划管制对区域经济发展的影响及其作 用机制，提出应建立起管制弱化区域和管制强化区 域之间的横向财政转移支付机制, 使不同区域均能 享受到国土空间优化带来的福利提升。柴铎等 ${ }^{[14]}$ 基 于生态价值观, 以耕地生产、生活、生态“全价值”核 算为工具设计了横向补偿关系测定方法。孙晶晶 等 ${ }^{[15]}$ 运用粮食安全法测算省域耕地资源盈亏量, 并 运用机会成本法测算省域耕地保护经济补偿标准, 为建立区际耕地保护经济补偿机制提供理论借鉴 和决策参考。张治会等 ${ }^{[16]}$ 以安徽省为例, 基于机会 成本损失从市域层面探讨区际耕地保护补偿机 制。曹瑞芬等 ${ }^{[17-19]}$ 分别基于地方政府经济福利、生 态服务价值、耕地资源净外部性等视角, 从省域、县 域尺度尝试构建跨区域财政转移机制。实际中, 中 国以新增建设用地土地有偿使用费 (以下简称新增 费) 为载体的财政转移制度可被视为一种横向跨区 域财政转移机制, 其通过新增费缴纳和新增费分 配,使得财政资金由非农发展区流向耕地保护区， 缩小了非农发展区与耕地保护区的地方财政差距、 调动了地方政府保护耕地的积极性。其中, 新增费 是指国务院或省级人民政府在批准农用地转用、征 用土地时, 向取得出让等有偿使用方式的新增建设 用地的县、市人民政府收取的平均土地纯收益。新 增费制度自 1999年实施以来, 如今已近 20 年, 其成 效如何, 应该怎样改进和完善, 近年来成为学术界 研究的焦点。然而, 现有研究主要围绕新增费缴纳 的耕地保护绩效评价 ${ }^{[20,21]}$, 或者旨在提高土地整治 效果的新增费分配方案设计 ${ }^{[2,23]}$, 将新增费缴纳、新 增费分配作为有机整体的研究几乎没有。本文初 步尝试将新增费缴纳、新增费分配过程有机结合， 视为省际横向跨区域财政转移支付, 即新增费由耕 地保护任务轻的非农发展区流向耕地保护任务重 的农地保护区, 并评价这种以新增费为载体的跨区 域财政转移支付制度的耕地保护效果。

本文的主要目的是尝试探讨以新增费为载体 的跨区域财政转移制度的耕地保护作用机理, 并采 用中国 2005-2015 年间省级面板数据进行实证研
度是否平衡了耕地保护区与非农发展区的财政可 支配能力, 进而达到调动地方政府保护耕地积极 性、促进耕地资源保护的目的。另外,本文将进一 步对比新增费缴纳和新增费分配的耕地保护效果， 为提高跨区域财政转移制度绩效提供参考依据。

\section{2 理论分析与模型设定}

\section{1 理论分析}

现有研究普遍认为, 保护耕地意味着土地发展 权的丧失 ${ }^{[24,25]}$ 。就地方政府而言,耕地转换为建设 用地,一方面会在短期内带来以土地出让金为主的 土地财政收人。赵文哲等 ${ }^{[26]}$ 指出分税制下土地出让 是地方政府缓解财政缺口压力的重要渠道。面对 地方财政人不敷出境况日益加重,地方政府利用其 对土地一级市场的绝对垄断地位, 在土地监管制度 不健全的情况下, 热衷于追求土地财政,获取大量 的出让金收人。另一方面, 从长远看,农地转变为 工商住宅用地,会给地方政府带来稳定持久的税收 收人,有利于地方财政收人的积累。方红生等 ${ }^{[27}$ 指 出,地方财政收人的主要来源是二、三产业,制造业 的快速发展不仅给地方政府带来稳定持久的增值 税和企业所得税等直接收益, 而且还为其带来大量 的营业税和高额的土地出让收人等间接收益, 其中 间接收益的取得得益于制造业的发展对于商业和 房地产业等服务业发展的强大溢出效应(即产业关 联效应)及其地方政府通过对土地市场的垄断而获 取的高地价。因此,耕地保护任务越轻、建设用地 指标越多的地区, 二、三产业越发达,财政收人能力 越强, 反之亦然。鉴于此,作为理性人的地方政府 势必会放弃保护耕地，而热衷于大量占用耕地资 源, 发展二、三产业。然而,保护耕地具有重要的现 实意义,其所产生的生态效益和社会效益是建设用 地无法取代的, 大量耕地资源流失将会导致一系列 社会和生态环境问题, 因此,调动耕地保护主体 一地方政府保护耕地的积极性至关重要。

以新增费为载体的跨区域财政转移制度有助 于平衡耕地保护区与非农发展区的财政收人水平, 其通过抑制非农发展区建设占用耕地的动机以及 调动耕地保护区地方政府保护耕地的积极性,达到 耕地资源保护的目的。中国《新增建设用地土地有 
偿使用费收缴使用管理办法》(财综字 [1999]117号) 第二条规定,新增费是指国务院或省级人民政府在 批准农用地转用、征用土地时, 向取得出让等有偿 使用方式的新增建设用地的县、市人民政府收取的 平均土地纯收益。因此, 对于地方政府来说, 若其 建设占用耕地指标较多, 其所交纳的新增费就越 多。此外,《新增建设用地土地有偿使用费资金使

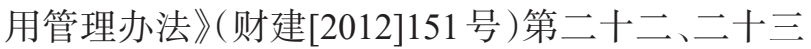
条规定, 中央对地方新增费转移支付支出采取因素 法、项目法或因素法与项目法相结合的方式分配。 且因素法分配新增费, 由财政部会同国土资源部综 合考虑各省(含自治区、直辖市、计划单列市、新疆 兵团)基本农田面积、灌溉水田面积和实际补充耕 地面积等因素确定资金分配方案, 重点支持中西部 地区和粮食主产区、产粮大县。意味着耕地保护任 务重的地区分配到的新增费较多。总而言之, 如果 某地区建设占用耕地指标较多,而耕地保护任务较 轻, 那么其缴纳的新增费可能会大于分配到的新增 费, 即为新增费净流出地区; 反之, 如果某地区耕地 保护任务较重, 而新增建设用地指标较少, 那么其 分配到的新增费就会大于缴纳的新增费, 即为新增
费净流人地区。假设 $n$ 个地方政府同属于上级政府 $m$,那么由上级政府 $m$ 统筹, 对 $n$ 个地方政府收取新 增费和分配新增费的行为可以被视为横向跨区域 财政转移支付, 即新增费由建设用地指标多的地区 向耕地保护任务重的地区转移。中国中央政府统 筹安排的对 31 个省级行政单位收取新增费和分配 新增费的过程即为省际横向跨区域财政转移支 付。定义净转移支付额为分配到的新增费减去缴 纳的新增费,那么新增费净流人地区的净转移支付 额大于零, 而新增费净流出地区的净转移支付额小 于零。至此,通过以新增费为载体的省际横向跨区 域财政转移支付, 可以达到平衡耕地保护区与非农 发展区财政收人水平的目的,进而调动地方政府保 护耕地积极性、促进耕地资源保护。以新增费为载 体的跨区域财政转移制度的耕地保护作用机理具 体见图1。

此外, 为了有针对性地实行财政制度改革, 提 高耕地保护绩效,本文进一步对比分析新增费缴纳 和新增费分配的耕地保护效果大小。实际中,相比 于新增费分配,中国新增费的缴纳更加科学规范。 相关文件 ${ }^{\mathbb{1}}$ 明确指出新增费的征收对象为取得出让

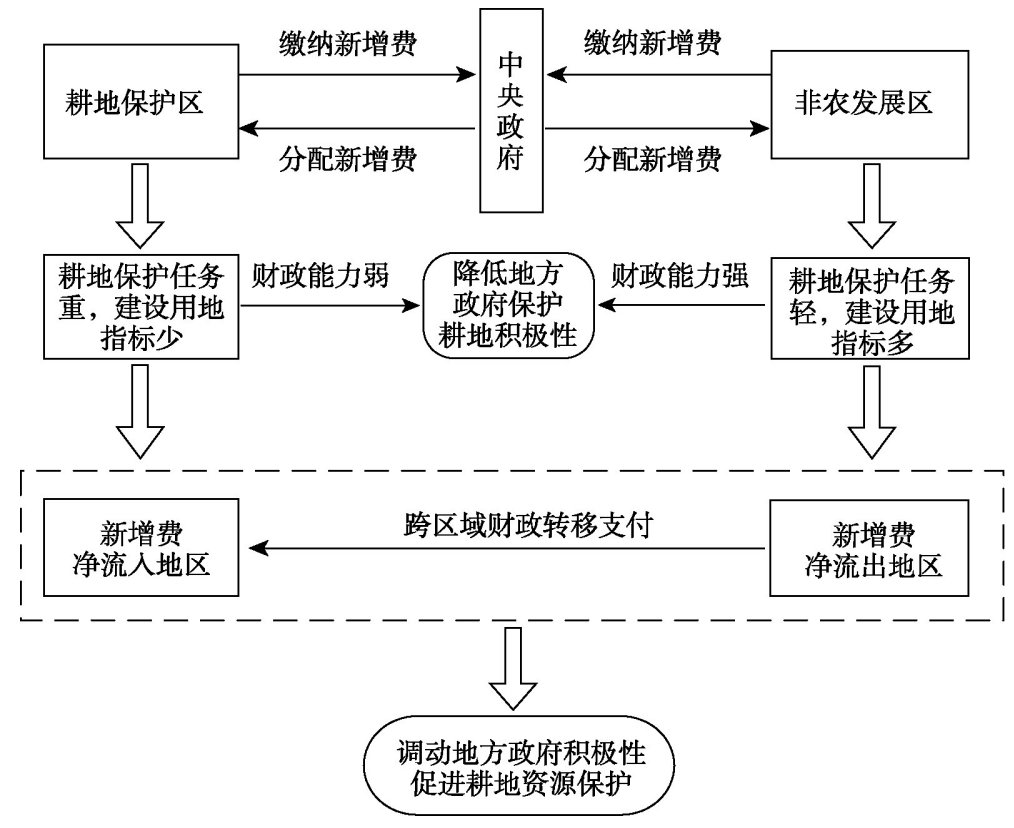

图 1 以新增费为载体的跨区域财政转移制度的耕地保护作用机理分析框架

Figure 1 Analytical framework of cultivated land protection mechanism of transregional fiscal payment with the fees for new construction land

(1) 相关文件具体指《新增建设用地土地有偿使用费收缴使用管理办法》(财综字[1999]117号)和《关于调整新增建设用地土地有偿使用费 政策等问题的通知》(财综[2006]48 号)。 
等有偿使用方式的新增建设用地的县、市人民政 府, 征收标准由 1999 年的 5 70 元 $/ \mathrm{m}^{2}$ 提高到 10 140 元 $/ \mathrm{m}^{2}$, 且新增费的 $30 \%$ 上缴中央财政, $70 \%$ 上缴地 方财政,征收程序规范、征收范围和征收标准明 确。而新增费分配属于专项转移支付, 透明度差、 随意性强。虽然中央分成新增费分配因素法的采 用在很大程度上提高了新增费分配的科学性, 减少 了地区间相互攀比的现象,有助于形成良性的区间 竞争关系, 然而由于因素法分配方式的实行尚处于 探索期和初级阶段,在实际操作过程中存在分配目 标不确定性、因素选取片面性和因素权重确定主观 性等问题 ${ }^{[22]}$,制约了财政资金的有效发挥,降低了新 增费分配的耕地保护效果。因此,理论上相比于新 增费分配, 新增费缴纳的耕地保护效果更好。通过 改革新增费分配制度可显著提高跨区域财政转移 制度耕地保护绩效。

\section{2 模型设定}

通常情况下,耕地保护或生态保护较好地区的 土地转换受到更严苛的管制, 国家对农业空间和生 态空间占有比例较大的地区会施以更高的国土空 间管制强度 ${ }^{[13]}$ 。换而言之, 耕地保护可能存在路径 依赖问题,即耕地保护较好地区会承受较强的国土 空间管制强度,耕地保护效果会更好。为此, 本文 构造如下的动态面板计量模型来考察以新增费为 载体的跨区域财政转移制度的耕地保护效应。

$$
\text { area }_{i t}=\beta_{0}+\beta_{1} \text { area }_{i t-1}+\beta_{2} \text { nettrans }_{i t}+\beta_{3} Z_{i t}+\varepsilon_{i t}
$$

式中: area $_{i t}$ 为被解释变量, 反映第 $i$ 地区第 $t$ 年的耕 地资源保护效果。钟太洋等 ${ }^{[28,29]}$ 依据土地督察和基 本农田保护政策的性质, 分别选用建设占用耕地面 积和年内减少耕地面积作为被解释变量, 研究土地 督察与基本农田保护政策对耕地资源流失的影响， 就二者的耕地保护效果进行评价; 郭春华等 ${ }^{[30]}$ 从土 地行政问责的性质出发,选取年内违法占用耕地面 积作为被解释变量, 对土地行政问责的耕地数量保 护效果进行分析。本文的研究对象是以新增费为 载体的跨区域财政转移制度, 其包含新增费交纳和 新增费分配。对于某一地区来说, 其一方面要为建 设占用耕地缴纳新增费; 另一方面, 其会以土地整 治项目为平台, 获取新增费用于耕地保护。换言 之, 新增费缴纳抑制了地方建设占用耕地的动机,
减少了耕地资源流失, 而新增费分配调动了地方保 护耕地的积极性, 促进了耕地资源增加, 二者的综 合效果体现在年末耕地保有量上。此外,考虑到中 国国土辽阔,各省级行政单位的区划面积差别较 大, 人口、耕地面积等也存在较大差别, 为客观反映 各省年末耕地资源状况,本文采用人均耕地面积作 为被解释变量, 这一指标值越大表明耕地保护效果 越好, 反之亦然。 area $_{i-1}$ 为滞后一年的人均耕地 面积。

nettrans $s_{i t}$ 代表以新增费为载体的跨区域财政转 移制度,根据前文的理论分析可知,由中央政府统 筹,对 31 个省级行政单位收取新增费和分配新增费 的行为可被视为省际横向跨区域财政转移支付,即 新增费由建设用地指标多的地区向耕地保护任务 重的地区转移。其中, 每个地区获得的净新增费, 即新增费分配与新增费缴纳之差可被用作衡量财 政转移支付水平,净新增费很高, 表明分配到的新 增费远远高于缴纳的新增费,进而说明耕地保护效 果越好, 反之亦然。根据理论分析, 本文预期其系 数为正,表明以新增费为载体的跨区域财政转移制 度有利于耕地资源保护。

$Z_{i t}$ 为控制变量, 参照已有研究 ${ }^{[2,2,2931,32]}$, 选择人均 GDP、城镇化水平、固定资产投资以及政策虚拟变 量 year $_{2007}$ 和 year ${ }_{2009}$ 作为控制变量。2006 年中国出 台《关于调整新增建设用地土地有偿使用费政策等 问题的通知》(财综 [2006]48 号), 规定从 2007 年 1 月 1 日起,新批准新增建设用地的土地有偿使用费 征收标准在原有基础上提高一倍,增加了地方政府 建设占用耕地的成本。此外,为了改进和完善新增 费的使用管理,建立相对科学的中央分成新增费分 配方式, 2007 年出台《关于调整中央分成的新增建 设用地土地有偿使用费分配方式的通知》(财建 [2007]84号),规定从 2007 年 1 月 1 日起,中央分成 新增费按照因素法分配至地方; 另外,2009年进一 步颁布了《关于中央分成的新增建设用地土地有偿 分配使用费使用及管理有关事项的通知》(财建 [2009］286 号),决定从 2009年起,将分配因素调整 为截至上一年 12 月 31 日的基本农田面积、灌溉水 田面积和实际补充耕地 (不含建设占用补充的耕 地)面积。因此,引人年度虚拟变量year ${ }_{2007}$ 和 year ${ }_{2009}$ 
控制政策制度的影响。然而模型回归结果显示, 变 量固定资产投资 year $_{2007}$ 和 year ${ }_{2009}$ 均不显著, 因此从 模型中剔除, 仅保留人均 GDP 和城镇化水平作为控 制变量。其中, 选用人均 GDP 作为地区经济发展水 平的一个代理变量 ${ }^{[33-35}$ 来控制经济增长对耕地资源 数量的影响。目前已有研究对于人均 GDP 与耕地 面积减少之间的关系形式还存在争议 ${ }^{[36]}$ 。城镇化是 耕地资源数量变化的重要驱动力, 选取目前应用广 泛的城镇化率指标来度量 ${ }^{[37]}$, 城镇化率即城镇人口 占总人口的比重。目前学术界就城镇化发展对耕 地的影响存在着争论, 主流观点认为城镇化使大量 的耕地减少, 影响着国家的粮食自给能力 ${ }^{[38]}$ 。但也 有不少学者认为, 由于城镇的人均建设用地少于农 村, 城镇化对保护耕地会起积极的促进作用 ${ }^{[39-42]}$ 。 $\beta_{0}$ 为常数项; $\varepsilon_{i t}$ 为随机误差项; 下标 $i 、 t$ 分别代表地区 和年份。

另外, 为了进一步考察新增费的两个组成部分 一一新增费缴纳和新增费分配的耕地保护效果大 小, 以便有针对性地进行财政制度改革,将方程(1) 修正如下。

$$
\begin{aligned}
\text { area }_{i t}= & \beta_{0}+\beta_{1} \text { area }_{i t-1}+\beta_{21} \text { inttrans }_{i t}+ \\
& \beta_{22} \text { outtrans }_{i t}+\beta_{3} Z_{i t}+\varepsilon_{i t}
\end{aligned}
$$

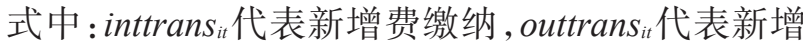
费分配。分别选取新增费缴纳中央分成部分和中 央分成新增费分配数额作为代理变量。根据理论 分析, 本文预期二者的系数均为正, 且前者大于后 者, 表明新增费分配、新增费缴纳均有助于耕地资 源保护, 且新增费缴纳的耕地保护效果大于新增费 分配。其他变量的解释同方程 (1)。

\section{3 实证结果及分析}

\section{1 数据来源及说明}

考虑到数据可得性, 本文采用2005-2015 年间 省级面板数据进行实证检验。其中, 耕地资源数据 来源于历年《中国统计年鉴》。鉴于 2009 年后公布 的耕地面积是采用基于全国第二次土地调查基础 上的变更调查结果, 为了保证统计口径的一致性, 首先, 将 2009 年数据对接为基于全国第一次土地调 查基础上的变更调查数据, 对接方法为以 2008 年为 基期年,采用 2008 年和 2010 年耕地资源变化速率 的平均值作为 2009 年耕地资源变化速率, 计算 2009
年耕地面积;然后以对接后的 2009 年耕地面积为基 础,依据 2010-2015 年各年耕地增减变化速率推算 2009 年以后的耕地面积。新增费数据来源于国土 资源部。其他经济社会数据, 如人均 GDP、城镇人 口、常住人口等数据主要来源于历年《中国统计年 鉴》。此外, 为了消除价格影响, 文中将各年人均 GDP、新增费等经济变量根据居民消费价格指数折 算为 2005 年可比价。

\section{2 结果分析}

结合数据来源, 采用系统广义矩方法 (SYS$\mathrm{GMM}$ )对 (1)至 (2)式进行估计。表 1 为以新增费为 载体的跨区域财政转移制度的耕地保护效应。其 中, 模型一、模型二分别对应净转移支付、分项转移 支付的耕地保护效应。

由表 1 可知, 文中模型一、模型二均通过了 Sargan 检验 (Sargan 检验的原假设为, 所有工具变量都 有效) 和 $\mathrm{AR}(2)$ 检验 $(\mathrm{AR}(2)$ 检验的原假设为, 扰动 项无自相关), 表明所使用的工具变量有效和模型 设定正确。被解释变量一人均耕地面积的滞后 项 $(\operatorname{area}(-1))$ 系数分别为 0.9905 和 0.9924 , 且具有 很好的统计显著性,证实了耕地资源保护具有较强 的路径依赖性。

由模型一的估计结果可知,核心解释变量以新增费为载体的省际横向跨区域财政转移制度 (nettrans) 有助于耕地资源保护, 其回归系数为

\section{表 1 跨区域财政转移制度耕地保护效应}

Table 1 The cultivated land protection effect of transregional fiscal

\begin{tabular}{|c|c|c|c|c|}
\hline \multirow{2}{*}{ 变量 } & \multicolumn{2}{|c|}{ 模型一 } & \multicolumn{2}{|c|}{ 模型二 } \\
\hline & 系数 & $z$ 值 & 系数 & $z$ 值 \\
\hline $\operatorname{area}(-1)$ & $0.9905 * * *$ & 1558.88 & $0.9924 * * *$ & 1301.61 \\
\hline nettrans & $0.0003 * * *$ & 7.39 & & \\
\hline inttrans & & & $0.0011 * * *$ & 12.02 \\
\hline outtrans & & & $0.0004 * * *$ & 16.15 \\
\hline gdpper & $-0.0124 * * *$ & -9.57 & $-0.0152 * * *$ & -6.59 \\
\hline$u r b$ & $0.0005 * * *$ & 9.87 & $0.0008 * * *$ & 5.94 \\
\hline cons & 0.0006 & 0.23 & $-0.0158 * * *$ & -4.59 \\
\hline $\mathrm{AR}(1)$ & & 0.0548 & & 0.0470 \\
\hline $\operatorname{AR}(2)$ & & 0.0726 & & 0.0630 \\
\hline Sargan test & & 0.9998 & & 1.0000 \\
\hline
\end{tabular}
payment system

注: $* * * * * *$ 分别表示在 $10 \% 、 5 \%$ 和 $1 \%$ 水平上显著; $\mathrm{AR}(1)$ 、 $\operatorname{AR}(2)$ 和 Sargan test 给出的是统计量对应的 $P$ 值。 
0.0003 , 且具有很好的统计显著性, 这与理论预期完 全一致。然而其系数绝对值较小, 说明近年来以新 增费为载体的跨区域财政转移制度虽有助于耕地 资源保护, 但其发挥的作用非常有限。研究结论与 已有研究成果一致,丁宁等 ${ }^{[20]}$ 基于中国 2003-2008 年省级面板数据的研究表明, 土地有偿使用费耕地 保护总体绩效不高,作用发挥较为有限。金晓斌 等 ${ }^{[2]}$ 研究发现, 新增费的设立增加了地方政府用地 成本, 对抑制耕地占用的规模和速度具有一定作 用, 但其耕地保护效果尚不显著, 贡献度仍较为有 限。由模型二的估计结果可知, 新增费的两个主要 组成部分一一新增费缴纳 (inttrans) 、新增费分配 (outtrans)均有助于耕地资源保护。而且相比于新 增费分配, 新增费缴纳的耕地保护效果更好, 其回 归系数分别为 0.0004 和 0.0011 , 且具有很好的统计 显著性, 这与理论预期完全一致。因此, 加大新增 费分配力度、改革新增费分配方法, 能够显著增强 耕地资源保护效果。其中, 新增费缴纳和新增费分 配的回归系数均较小,主要原因在于: 中国新增费 缴纳过程虽科学规范, 然而由于缴纳标准相对较 低, 目前征收标准为 $10 \sim 140$ 元 $/ \mathrm{m}^{2}$, 与建设占用耕地 可能带来的巨大利益相比微乎其微, 因此其在抑制 地方政府建设占用耕地动机方面发挥的作用非常 有限。对于新增费分配来说, 中国新增费分配属于 专项转移支付, 在整个转移支付体系中所占比重较 小, 据统计 2005-2015 年间中央分成新增费分配额 分别占中央转移支付资金的 $1.90 \% 、 0.62 \% 、 1.85 \%$ 、 $0.47 \% 、 0.55 \% 、 0.77 \% 、 0.87 \% 、 1.02 \% 、 0.71 \% 、 0.54 \%$ 、 $0.44 \%$, 均低于 $2 \%$, 加之新增费分配方法不完善, 导 致财政资金发挥作用更加有限。对于控制变量, 本 文发现经济发展水平 (gdpper) 对耕地资源保护具有 显著的负效应, 说明近年来虽然中国的经济发展水 平相对较高, 集约化程度不断提高, 但经济增长对 土地的刚性需求依然很大。城镇化水平 (urb) 对耕 地资源保护具有显著的正效应, 说明中国城镇土地 利用效率和集约度不断提升, 粗放式的建设用地扩 张模式正在逐步改变。

\section{4 讨论与结论}

\section{1 讨论}

由于目前中国尚未正式实施地区间横向耕地
保护补偿政策 ${ }^{[14,43]}$, 因此,现有研究仅局限于探讨跨 区域耕地保护补偿机制的构建。本文初步尝试将 新增费缴纳、新增费分配过程有机结合,视为中央 政府统筹的省际横向跨区域财政转移支付,并就其 耕地保护效应进行分析, 是对现有研究的补充和完 善。此外,本文进一步探讨新增费的两个主要组成 部分一一新增费缴纳和新增费分配的耕地保护效 应大小, 以便有针对性地进行财政制度改革, 是对 研究的扩展和深化。

实证检验方面,考虑到因变量——耕地保护效 果可能存在路径依赖问题, 本文通过构建动态面板 计量模型进行研究,并采用系统 GMM 方法进行估 计, 解决了模型中引人被解释变量的滞后项作为解 释变量带来的内生性问题, 模型选择和估计方法均 科学可靠。另外,考虑到自 2009年起公布的耕地面 积采用的是全国第二次土地调查数据成果,与 2009 年前公布的耕地面积存在较大差别, 为保证数据统 计口径一致性,本文将 2009-2015 年间耕地资源面 积对接为基于全国第一次土地调查基础上的变更 调查数据, 对接方法具有一定的科学性。然而, 由 于对接后的数据可能与实际数据存在偏差, 进而导 致估计结果出现偏误，因此后期可进一步探讨其他 对接方法,并进行对比研究,保证研究结果更加准 确可靠。

本文研究结果与理论预期一致,且与已有研究 成果相符 ${ }^{[20,21]}$, 研究有助于完善以新增费为载体的 省际横向跨区域财政转移支付制度,促进耕地资源 保护。然而,考虑到县级行政单位是中国新增费缴 纳和分配的基本单元, 因此,基于县级尺度探讨以 新增费为载体的跨区域财政转移制度的耕地保护 效应,并据此提出可供参考的政策建议可能更具有 现实意义。后续可进一步针对不同类型省级行政 单位,研究省以下县级地方政府间跨区域财政转移 制度的耕地保护效应，以实行差别化的财政制度 改革。

最后, 考虑到耕地质量等级调查评定成果的时 间序列数据获取困难,且学术界就耕地生态属性的 度量尚未达成共识, 文中耕地保护效果仍以耕地数 量衡量。然而,随着耕地“三位”一体保护体系逐渐 形成,在耕地保护效应分析或者跨区域财政转移过 
程中, 理应关注耕地的“三位”一体保护, 后期可进 一步尝试构建全面考虑耕地数量、质量、生态属性 的综合指标进行分析。

\section{2 结论}

跨区域财政转移制度是解决耕地保护区域非 均衡的重要工具, 其通过管制弱化区域和管制强化 区域之间的横向财政转移,使得不同区域均能享受 到国土空间优化带来的福利提升 ${ }^{[13]}$, 有助于耕地保 护的实施。本文以新增费为例, 探讨跨区域财政转 移制度的耕地保护作用机理, 并采用中国 20052015 年间省级面板数据进行实证检验。

(1) 理论分析与实证研究表明, 以新增费为载 体的省际横向跨区域财政转移支付制度有助于耕 地资源保护, 但是其发挥的作用非常有限。研究结 论解释了新增费制度实施后地方政府仍热衷于争 取建设用地指标的原因, 提出了财政制度改革的 需求。

(2)本文进一步探讨了新增费的两个主要组成 部分一一新增费缴纳和新增费分配的耕地保护效 应大小, 以便有针对性地进行财政制度改革。结果 表明,相比于新增费分配, 新增费缴纳的耕地保护 效果更好。因此,加大新增费分配力度、改革新增 费分配方法, 能够显著增强耕地资源保护效果。

\section{参考文献(References):}

[1] 杨立, 王博祺, 韩锋. 改革开放以来我国耕地保护绩效定量研 究: 基于数量保护的视角[J]. 农机化研究, 2015, (3): 1-5. [Yang L, Wang B Q, Han F. A quantitative study on the performance of cultivated land protection in China since the reform and opening up: Based on the angel of protection[J]. Journal of Agricultural Mechanization Research, 2015, (3): 1-5.]

[2] 萧景楷. 农地环境保育效益之评价[J]. 水土保持研究, 1999, 6 (3): 60-71. [Xiao J K. The valuation of environmental benefits for farmland[J]. Research of Soil and Water Conservation, 1999, 6(3): 60-71.]

[3] 钱忠好. 中国农地保护: 理论与政策分析[J]. 管理世界, 2003, (10): 60-70. [Qian Z H. Farmland protection in China: Theory and policy analysis[J]. Management World, 2003, (10): 60-70.]

[4] Ye X Y, Wei Y D. Geospatial analysis of regional development in China: The case of Zhejiang Province and the Wenzhou model[J]. Eurasian Geography and Economics, 2005, 46(6): 445-464.
[ 5 ] Deng X Z, Huang J K, Rozelle S, et al. Cultivated land conversion and potential agricultural productivity in China[J]. Land Use Policy, 2006, 23(4): 372-384.

[6] Deng X Z, Huang J K, Rozelle S, et al. Impact of urbanization on cultivated land changes in China[J]. Land Use Policy, 2015, 45: 1-7.

[ 7 ] Jiang L, Deng X Z, Seto K C. Multi-level modeling of urban expansion and cultivated land conversion for urban hotspot counties in China[J]. Landscape and Urban Planning, 2012, 108(2-4): 131139.

[8] Wei Y D, Ye X Y. Urbanization, urban land expansion and environmental change in China[J]. Stochastic Environmental Research Risk Assessment, 2014, 28(4): 757-765.

[9] Chen W X, Ye X Y, Li J F. Analyzing requisition-compensation balance of farmland policy in China through telecoupling: A case study in the middle reaches of Yangtze River urban agglomerations [J]. Land Use Policy, 2019, 83: 134-146.

[10] 马海涛, 任致伟. 转移支付对县级财力均等化的作用 [J]. 财政研 究, 2017, (5): 2-12. [Ma H T, Ren Z W. The equalization effect of transfer payment on counties' financial resources[J]. Public Finance Research, 2017, (5): 2-12.]

[11] 李邭, 洪国志, 黄亮雄. 中国土地财政增长之谜: 分税制改革、土 地财政增长的策略性[J]. 经济学(季刊), 2013, 12(4): 11411159. [Li X, Hong G Z, Huang L X. The mystery of land finance growth in China: Tax-sharing reform, strategic interaction of land finance[J]. China Economic Quarterly, 2013, 12(4): 1141-1159.]

[12] 雍新琴, 张安录. 基于粮食安全的耕地保护补偿标准探讨 [J]. 资 源科学, 2012, 34(4): 749-757. [Yong X Q, Zhang A L. Discussion on the compensation standard of the arable land protection based on food security[J]. Resources Science, 2012, 34(4): 749757.]

[13] 余亮亮,蔡银蒀. 国土空间规划管制、地方政府竞争与区域经济 发展: 来自湖北省县(市、区)域的经验研究[J]. 中国土地科学, 2018, 32(5): 54-61. [Yu L L, Cai Y Y. Spatial regulation of land use planning, local government competition and regional economic development: Empirical evidence from the counties (cities, districts) of Hubei Province[J]. China Land Sciences, 2018, 32(5): 54-61.]

[14] 柴铎, 林梦柔. 基于耕地“全价值”核算的省际横向耕地保护补 偿理论与实证[J]. 当代经济科学, 2018, 40(2): 69-77. [Chai D, Lin M R. The theoretical mechanism and empirical division of the provincial farmland protection compensation based on "total value” accounting[J]. Modern Economic Science, 2018, 40(2): 6977.]

[15] 孙晶晶, 赵凯, 曹慧, 等. 我国耕地保护经济补偿分区及其补偿 额度测算: 基于省级耕地-经济协调性视角 [J]. 自然资源学报, 2018, 33(6): 1003-1017. [Sun J J, Zhao K, Cao H, et al. Zoning 
and quantity of economic compensation for arable land protection: From the perspective of coordination between provincial cultivated land and economic[J]. Journal of Natural Resources, 2018, 33 (6): 1003-1017.]

[16] 张治会, 李全新. 基于机会成本损失的区际地方政府耕地保护 补偿研究: 以安徽省各市域为例[J]. 管理现代化, 2017, (1): 3335. [Zhang Z H, Li Q X. Research on interregional local government's farmland protection compensation based on opportunity cost loss: A case study of municipalities in Anhui Province[J] Modernization of Management, 2017, (1): 33-35.]

[17] 曹瑞芬, 张安录. 耕地保护补偿标准及跨区域财政转移机制: 基 于地方政府经济福利视角的研究 $[J]$. 中国人口. 资源与环境, 2015, 25(10): 132-138. [Cao R F, Zhang A L. Compensation standard of cultivated land protection and mechanism of trans-regional fiscal payment: From the perspective of local government economic welfare[J]. China Population, Resources and Environment, 2015, 25(10): 132-138.]

[18] 曹瑞芬, 张安录, 万珂. 耕地保护优先序省际差异及跨区域财政 转移机制: 基于耕地生态足迹与生态服务价值的实证分析 [J]. 中国人口・资源与环境, 2015, 25(8): 34-42. [Cao R F, Zhang A L, Wan K. Provincial differences in priority of cultivated land protection and mechanism of trans-regional fiscal payment: An empirical analysis based on ecological footprint and service value[J]. China Population, Resources and Environment, 2015, 25(8): 3442.]

[19] 曹瑞芬, 张安录. 湖北省耕地资源净外部性价值量测算及财政 转移支付 [J]. 资源科学, 2014, 36(6): 1211-1219. [Cao R F, Zhang A L. Assessing the net externalities of cultivated land and fiscal transfer payment in Hubei[J]. Resources Science, 2014, 36 (6): 1211-1219.]

[20] 丁宁, 金晓斌, 唐健, 等. 新增建设用地使用费的耕地保护绩效 测算[J]. 自然资源学报, 2011, 26(7): 1096-1106. [Ding N, Jin X B, Tang J, et al. Effect in protecting cultivated land of new construction land compensation fee[J]. Journal of Natural Resources, 2011, 26(7): 1096-1106.]

[21] 金晓斌, 丁宁, 唐健, 等. 新增建设用地土地有偿使用费征收标 准调整对耕地保护效果影响的计量分析: 以江苏省为例[J]. 地 理科学, 2011, 31(7): 817-822. [Jin X B, Ding N, Tang J, et al. Protecting cultivated land of standard changes for new construction land compensation fee: A case study on Jiangsu Province, China[J]. Scientia Geographica Sinica, 2011, 31(7): 817-821.]

[22] 丁宁. 中央分成新增费分配方案的土地整治效果预期分析[D]. 南京: 南京大学, 2012. [Ding N. Analysis of Expected Benefit for Land Consolidation of the Allocation for New Construction Land Compensation Fee[D]. Nanjing: Nanjing University, 2012.]

[23] 金晓斌, 丁宁, 张志宏, 等. 中国土地整治资金在省际间分配及
土地整治效果[J]. 农业工程学报, 2012, 28(16): 1-9. [Jin X B, Ding N, Zhang Z H, et al. Inter-provincial allocation of land consolidation fund and effects of land consolidation in China[J]. Transactions of the Chinese Society of Agricultural Engineering, 2012, 28(16): 1-9.]

[24] 汪晗, 聂金金, 张安录. 武汉市农地发展权定价研究[J]. 中国土地 科学, 2011, 25(7): 66-71. [Wang H, Nie X, Zhang A L. Empirical study on farmland development right pricing: A case study of $\mathrm{Wu}$ han City[J]. China Land Science, 2011, 25(7): 66-71.]

[25] 宋戈, 柳清, 王越. 基于耕地发展权价值的东北粮食主产区耕地 保护补偿机制研究[J]. 中国土地科学, 2014, 28(6): 58-64 [Song G, Liu Q, Wang Y. Study on compensation mechanism for cultivated land protection in northeast major grain producing areas based on the value of farmland development rights[J]. China Land Science, 2014, 28(6): 58-64.]

[26] 赵文哲, 杨继东. 地方政府财政缺口与土地出让方式: 基于地方 政府与国有企业互利行为的解释[J]. 管理世界, 2015, (4): 1124. [Zhao W Z, Yang J D. Local government financial gap and land supply mode: Based on interpretation of mutual benefit behavior between local government and state-owned enterprises[J]. Management World, 2015, (4): 11-24.]

[27] 方红生, 张军. 财政集权的激励效应再评估: 擢取之手还是援助 之手[J]. 管理世界, 2014, (2): 21-31. [Fang H S, Zhang J. A reevaluation of the incentive effects of the fiscal centralization: Is it a grabbing hand or a helping hand?[J]. Management World, 2014, (2): 21-31.]

[28] 钟太洋, 黄贤金, 谭梦, 等. 土地督察的耕地保护效果评价[J]. 中 国人口・资源与环境, 2011, 21(5): 38-43. [Zhong T Y, Huang X J, Tan M, et al. Arable land conservation effects of land supervision in China[J]. China Population, Resources and Environment, 2011, 21(5): 38-43.]

[29] 钟太洋, 黄贤金, 陈逸. 基本农田保护政策的耕地保护效果评价 [J]. 中国人口・资源与环境, 2012, 22(1): 90-95. [Zhong T Y, Huang X J, Chen Y. Arable land conversion effects of basic farmland protection policy[J]. China Population, Resources and Environment, 2012, 22(1): 90-95.]

[30] 郭春华, 黄彪. 土地行政问责对耕地保护的效果评价: 以江苏 省为例 [J]. 资源科学, 2013, 35(12): 2384-2389. [Guo C H, Huang B. Land administrative accountability for farmland protection in Jiangsu Province[J]. Resources Science, 2013, 35(12): 2384-2389.]

[31] 张全景, 欧名豪, 王万茂. 中国土地用途管制制度的耕地保护绩 效及其区域差异研究[J]. 中国土地科学, 2008, 22(9): 8-13. [Zhang Q J, Ou M H, Wang W M. Study on cultivated land preservation performance of land use control system and its regional differences in China[J]. China Land Sciences, 2008, 22(9): 8-13.] 
[32] 金雨泽, 徐智颖, 钟太洋, 等. 我国土地利用动态监测的耕地保 护效果评价[J]. 地域研究与开发, 2016, 35(5): 120-123. [Jin Y

Z, Xu Z Y, Zhong T Y, et al. Arable land conservation effects of land use dynamic monitoring in China[J]. Areal Research and Development, 2016, 35(5): 120-123.]

[33] 李永乐, 吴群. 中国经济增长与耕地资源数量变化阶段性特征 研究: 协整分析及 Granger 因果检验[J]. 长江流域资源与环境, 2011, 20(1): 33-38. [Li Y L, Wu Q. Economic growth and quantity change of cultivated land: Co- integration analysis and granger causality test[J]. Resources and Environment in the Yangtze Basin, 2011, 20(1): 33-38.]

[34] 刘荣茂, 张莉侠, 孟令杰. 经济增长与环境质量: 来自中国省际 面板数据的证据[J]. 经济地理, 2006, 26(3): 374-377. [Liu R M, Zhang L X, Meng L J. Economic growth and environmental quality: Evidence from provincial panel data in China[J]. Economic Geography, 2006, 26(3): 374-377.]

[35] 张嫘, 方天斿. 我国城乡收人差距变化与经济增长的协整及因 果关系分析[J]. 农业技术经济, 2007, (3): 38-43. [Zhang L, Fang $\mathrm{T}$ K. Changes in the urban- rural income gaps and economic growth: An analysis on their coordination, causes and effects[J]. Journal of Agrotechnical Economics, 2007, (3): 38-43.]

[36] 胡建民, 石忆邵. 略论耕地库兹涅茨曲线在我国的适用性[J]. 长 江流域资源与环境, 2008, 17(4): 588-592. [Hu J M, Shi Y S. Discussion on the applicability of cultivated land Kuznets curve in China[J]. Resources and Environment in the Yangtze Basin, 2008, 17(4): 588-592.]

[37] 贾云䏒. 城镇化、工业化、农业现代化与经济增长关系研究 [J]. 城市发展研究, 2012, 19(12): 27-32. [Jia Y Y. Relationship of urbanization, industrialization, agricultural modernization and eco- nomic growth[J]. Urban Development Studies, 2012, 19(12): 2732.]

[38] 封志明, 李香莲. 耕地与粮食安全战略: 藏粮于土, 提高中国土 地资源的综合生产能力 [J]. 地理学与国土研究, 2000, 16(3): 1-

5. [Feng Z M, Li X L. The stratagem of cultivated land and food supplies security storing food in land raising the comprehensive productivity of land resource of China[J]. Geography and Territorial Research, 2000, 16(3): 1-5.]

[39] 贾绍凤, 张豪禧, 孟向京. 我国耕地变化趋势与对策再探讨 $[\mathrm{J}]$. 地理科学进展, 1997, 16(1): 24-29. [Jia S F, Zhang H X, Meng X J. Forecast and countermeasures of the change of the cultivated area of China[J]. Progress in Geography, 1997, 16(1): 24-29.]

[40] Huang J, Zhu L, Deng X, et al. Cultivated land changes in China: The impacts of urbanization and industrialization[J]. Society of Photo-Optical Instrumentation Engineers, 2005, 5884: 135-149.

[41] 宋戈, 吴次芳, 王杨. 城镇化发展与耕地保护关系研究[J]. 农业 经济问题, 2006, (1): 64-67. [Song G, Wu C F, Wang Y. Urbanization and protection of farmland[J]. Issues in Agricultural Economy, 2006, (1): 64-67.]

[42] 朱莉芬, 黄季焜. 城镇化对耕地影响的研究[J]. 经济研究, 2007, (2): 137-144. [Zhu L F, Huang J K. Urbanization and cultivated land changes in China[J]. Economic Research Journal, 2007, (2): 137-144.]

[43] 牛海鹏, 肖东洋. 耕地保护经济补偿效应研究进展与述评: 比 较与借鉴[J]. 资源开发与市场, 2016, 32(11): 1340-1346. [Niu H P, Xiao D Y. Research progress and review on cultivated land protection economic compensation effects: Comparison and reference[J]. Resource Development \& Market, 2016, 32(11): 13401346. 


\title{
Effect of transregional fiscal payment system for cultivated land protection:
}

\author{
Taking new construction land compensation fees as an example
}

\author{
CAO Ruifen ${ }^{1}$, ZHANG Anlu² \\ (1. Department of Land Resources Management, Zhejiang Gongshang University, Hangzhou 310018, China; \\ 2. College of Land Management, Huazhong Agricultural University, Wuhan 430070, China)
}

\begin{abstract}
Transregional fiscal payment system is an important tool for addressing the issue of regional imbalance brought by cultivated land protection. Through horizontal fiscal transfer between areas with different regulatory intensity, the system enables different regions to share the dividends of land- use optimization, which is helpful to the implementation of cultivated land protection. This study comprehensively considered the processes of collecting and distributing the fees for new increased construction land and took the whole process as a kind of transregional fiscal payment, that is, the fees are transferred from the nonagricultural development zone with higher quota of construction land to the cultivated land protection zone with heavy farmland protection task. On this basis, it examined the arable land protection effect of this kind of transregional fiscal payment system with the fees for new increased construction land as the carrier. A dynamic panel data model and system generalized method of moments (SYS-GMM) estimation are employed to verify the theory by using the provincial level panel data in China from 2005 to 2015. The results show that the interprovincial horizontal fiscal transfer payment system based on the fees for new increased construction land could help to mobilize the local governments to protect cultivated land and serve the purpose of protecting arable land, but its role is very limited. Among the two components of the fees, compared to fee distribution, the cultivated land protection effect of fees collection is better in China. This research may contribute to improving the interprovincial horizontal fiscal transfer payment system based on the fees for new increased construction land and promote cultivated land protection.
\end{abstract}

Key words: cultivated land protection; effect analysis; transregional fiscal payment system; fees for new increased construction land; SYS-GMM 